\title{
Endometrioid Tumor
}

National Cancer Institute

\section{Source}

National Cancer Institute. Endometrioid Tumor. NCI Thesaurus. Code C7113.

A benign, borderline, or malignant epithelial tumor of the female reproductive system

characterized by the presence of glands and/or cysts lined by neoplastic cells that resemble endometrial cells. 